This is the final peer-reviewed accepted manuscript of

CATTÒ, SILVIA; Cavazza, William; Zattin, Massimiliano; Okay, Aral I.: No significant Alpine tectonic overprint on the Cimmerian Strandja Massif (SE Bulgaria and NW Turkey). INTERNATIONAL GEOLOGY REVIEW 60. ISSN 0020-6814

DOI: $10.1080 / 00206814.2017 .1350604$

The final published version is available online at:

http://dx.doi.org/10.1080/00206814.2017.1350604

Rights / License: The terms and conditions for the reuse of this version of the manuscript are specified in the publishing policy. For all terms of use and more information see the publisher's website. 


\title{
No significant Alpine tectonic overprint on the Cimmerian Strandja Massif (SE Bulgaria and NW Turkey)
}

\author{
Silvia Cattòa, William Cavazza ${ }^{a}$, Massimiliano Zattin ${ }^{\mathrm{b}}$ and Aral I. Okay

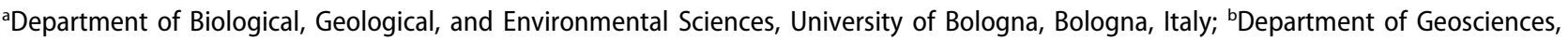 \\ University of Padua, Padua, Italy; 'Eurasia Institute of Earth Sciences, Istanbul Technical University, Istanbul, Turkey
}

\begin{abstract}
We provide the first comprehensive picture of the thermochronometric evolution of the Cimmerian Strandja metamorphic massif of SE Bulgaria and NW Turkey, concluding that the bulk of the massif has escaped significant Alpine-age deformation. Following Late Jurassic heat-ing, the central part of the massif underwent a Kimmeridgian-Berriasian phase of relatively rapid cooling followed by very slow cooling in Cretaceous-to-Early Eocene times. These results are consistent with a Late Jurassic-Early Cretaceous Neocimmerian (palaeo-Alpine) phase of north-verging thrust imbrication and regional metamorphism, followed by slow cooling/exhumation driven by erosion. From a thermochronometric viewpoint, the bulk of the Cimmerian Strandja orogen was largely unaffected by the compressional stress related to the closure of the Vardar-izmir-Ankara oceanic domain(s) to the south, contrary to the adjacent Rhodopes. Evidence of Alpine-age deformation is recorded only in the northern sector of the Strandja massif, where both basement and sedimentary rocks underwent cooling/exhumation associated with an important phase of shortening of the East Balkan fold-and-thrust belt starting in the Middle-Late Eocene. Such shortening focused in the former Srednogorie rift zone because this area had been rheolo-gically weakened by Late Cretaceous extension.
\end{abstract}

\author{
KEYWORDS \\ Strandja Massif; \\ low temperature \\ thermochronology; apatite \\ fission track analysis; \\ Cimmerian orogeny; Balkans
}

\section{Introduction}

The term 'Cimmerian orogeny' loosely refers to tectonic deformation ranging in age from the Late Triassic to the Early Cretaceous - a timespan of about $100 \mathrm{Ma}$ - and covering a wide area stretching west to east from the eastern Alps to the Far East over a distance in excess of $8000 \mathrm{~km}$ (see Şengör 1984, for a review). The notion of a continent-continent collision between a Gondwanaderived ribbon continent and the southern margin of Laurasia as the driving mechanism for Cimmerian deformation was first proposed by Şengör (1979) and has influenced geological thinking ever since, with minor variations (e.g. Dercourt et al. 1993; Ricou 1995). More recent geological research is pointing to a series of discrete and largely diachronous Cimmerian deformation events (Stampfli and Borel 2004; Stampfli and Hochard 2009; Okay et al. 2013, 2015; Topuz et al. 2013). From this viewpoint, the composite Cimmerian tectonic belt comprises a variety of geological objects, including the remnants of: (i) several oceanic basins, which opened starting from the Middle Permian and closed between the Late Triassic and the Cretaceous; (ii) a number of amalgamated pre-Alpine continental terranes resulting from the rifting of the Gondwanan margin, northward drift, and accretion to the European margin; and (iii) several oceanic volcanic arcs and plateaux locally accreted to the Laurasian margin without any large-scale continental collision. Such variety of accreted objects agrees well with the diachroneity and large geographic extent of the composite Cimmerian tectonic belt.

Main orogenic events related to terrane accretion along the southern Laurasian margin have been traditionally identified as Late Triassic - Liassic (Eocimmerian orogeny), Late Jurassic - Early Cretaceous (Neocimmerian orogeny), and Late Cretaceous -Miocene (Alpine orogeny lato sensu) (Şengör 1984; Khain 1994; Okay and Tüysüz 1999; Cavazza et al. 2004; Papanikolaou et al. 2004; Okay et al. 2010). Broadly speaking, Cimmerian-age tectonic elements are clearly distinguishable from the Far East to Iran, whereas they are more difficult to recognize across Asia Minor and the Balkan peninsula, where they were overprinted during later orogenic pulses. The distinction between Cimmerian and Alpine structural patterns 
is rather difficult. The picture is further complicated by back-arc oceanic basins (Halstatt-Meliata, Maliac, Pindos, and Crimea-Svanetia) which opened along the southern margin of Eurasia during subduction of Palaeotethys and which were mostly destroyed during the docking of the Cimmerian continental terranes (e.g. Stampfli and Hochard 2009).

The southern Balkan region bears evidence of Cimmerian-age deformation (e.g. Stampfli et al. 2001; Papanikolaou et al. 2004; Stampfli and Kozur 2006). This region features a large metamorphic assemblage comprising - west to east - the Serbo-Macedonian,
Rhodope, and Strandja massifs. The relationship between these metamorphic domains, and their ages of metamorphism are still poorly known (see Burchfiel and Nakov 2015, for a review). Such southern Balkan metamorphic assemblage is bound to the north by the Eocene-Oligocene Balkan thrust belt and to the south by the early Tertiary Vardar suture and the Intra-Pontide suture (Figure 1). The least known portion of the southern Balkan metamorphic province is the Strandja Massif to the northeast. In this paper, we provide the first lowtemperature thermochronometric data along a transect covering the whole width of the Strandja Massif, both

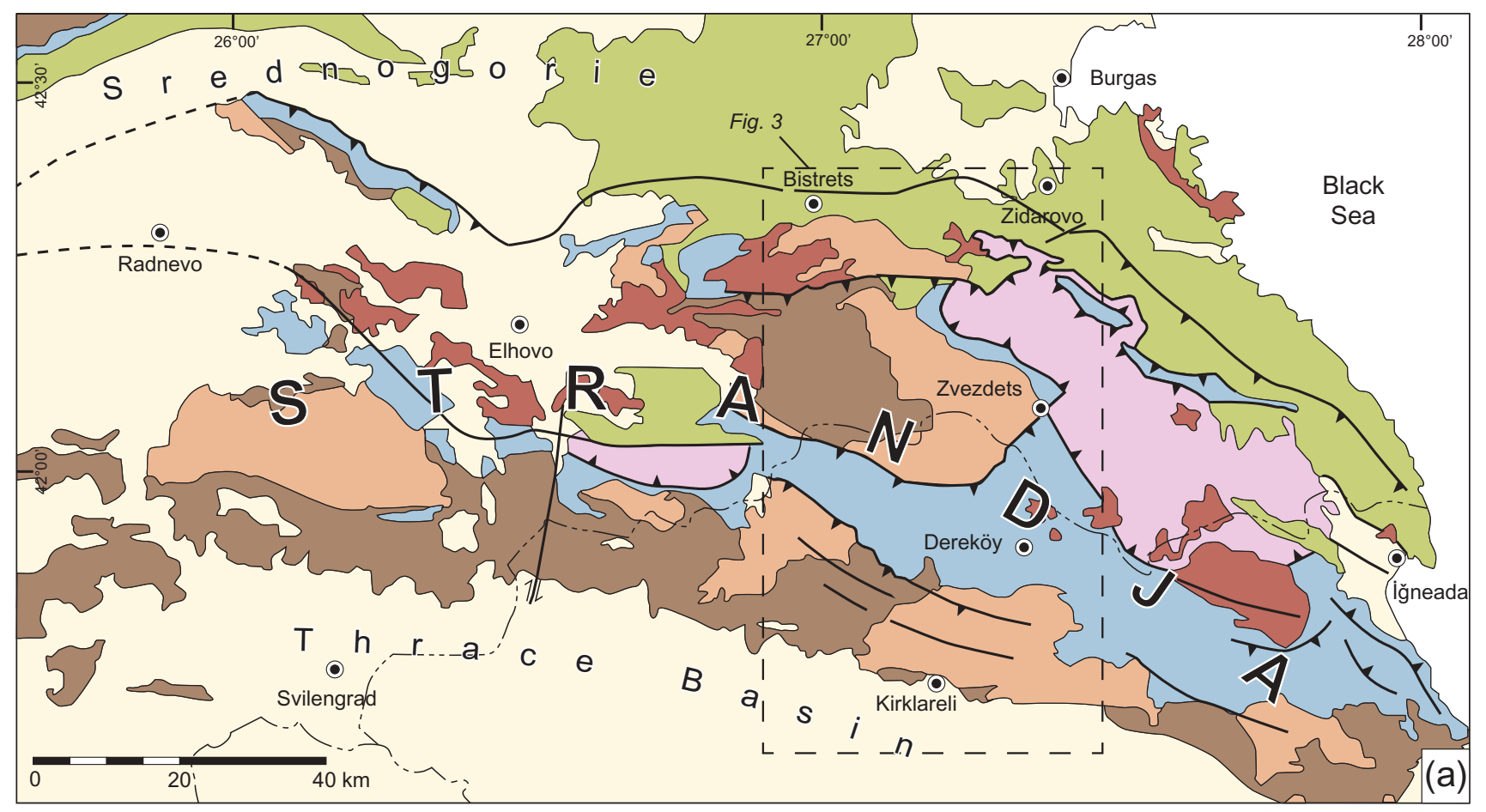

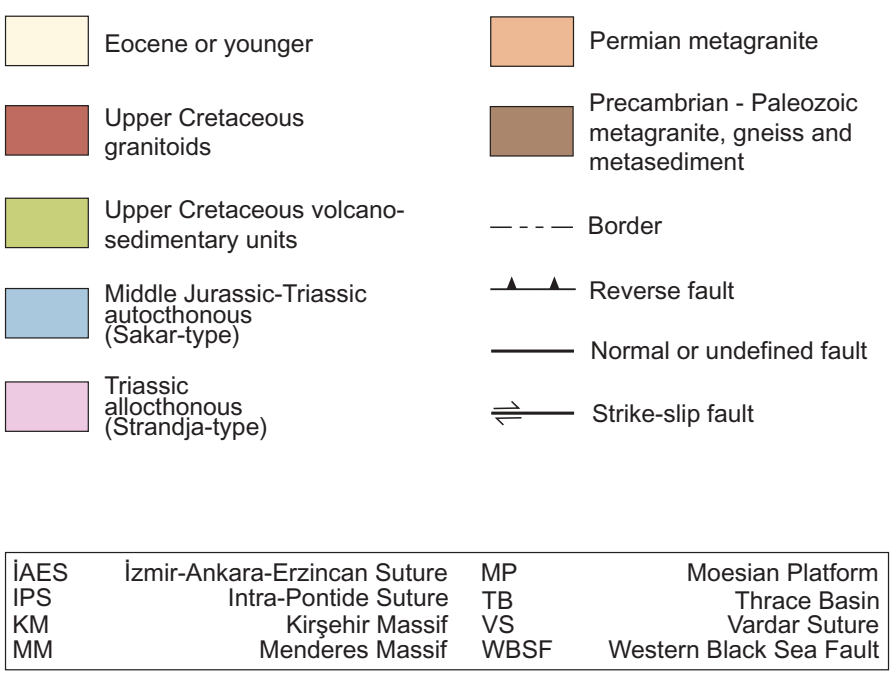

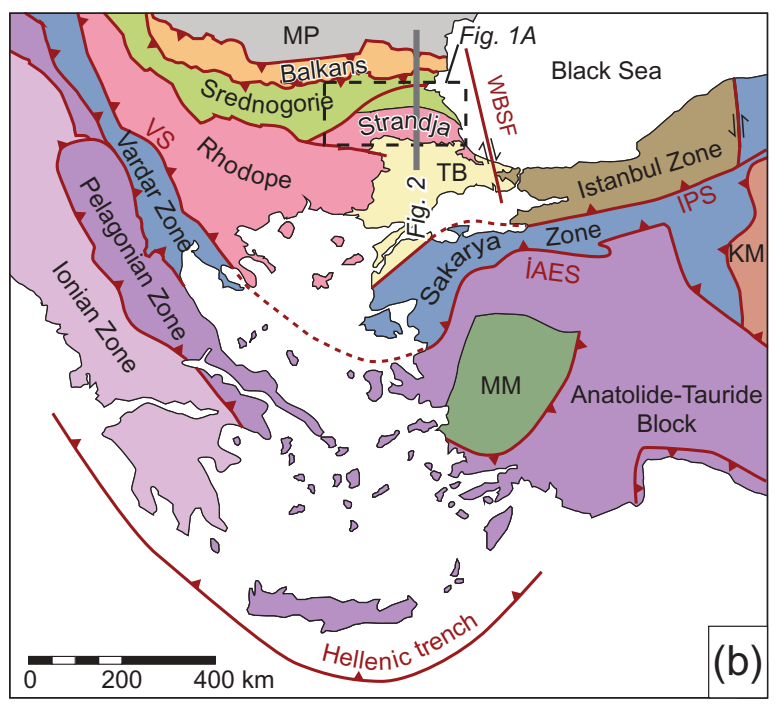

Figure 1. (a) Simplified geological map of the Strandja Massif; location of study area (Figure 3) is shown as a dashed box. (b) Main tectonic divisions and boundaries of the Aegean and periAegean region. 


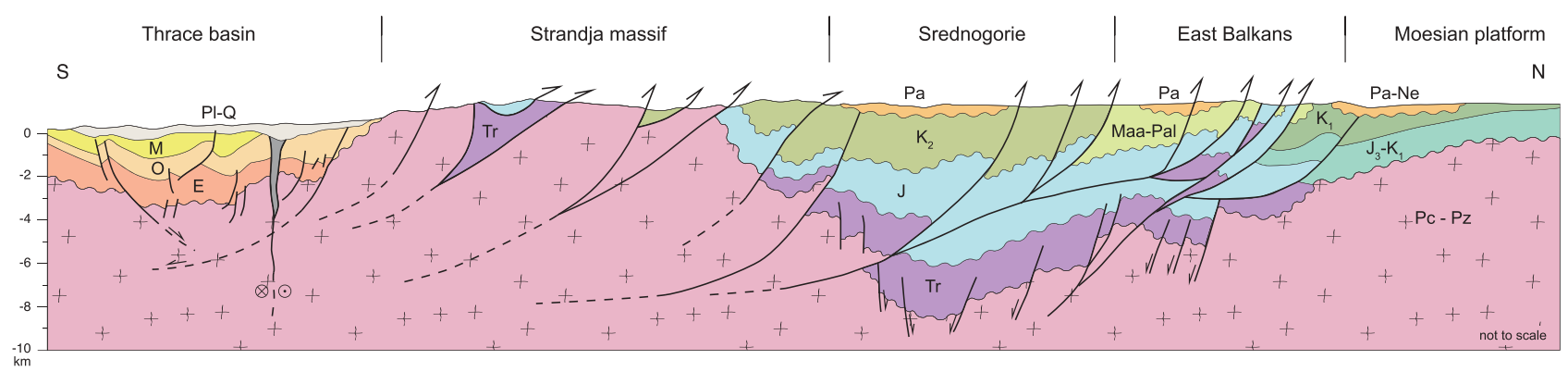

Figure 2. Schematic structural cross-section across the northern Thrace Basin, the Strandja Massif, the Srednogorie rift zone, and the southern Moesian Platform. Modified from Görür and Okay (1996), Georgiev et al. (2001), and Natal'in et al. (2012). Location of crosssection is shown in Figure 1.

in Bulgarian and Turkish territory. The integration of apatite fission-track (AFT) data with preexisting structural and radiometric data shows that the bulk of the massif did not undergo any significant thermal evolution during the Alpine tectonic cycle, thus basically retaining its Cimmerian-age structure. Alpine-age contractional deformation focused instead to the north of the massif to create the East Balkan thrust belt, whereas to the south late Eocene-Oligocene extension created the accommodation space for the thick deposits of the Thrace Basin (d'Atri et al. 2012; Cavazza et al. 2013) (Figure 2). From this viewpoint, the Strandja Massif is therefore one of very few areas in the perimediterranean region where Cimmerian-age tectonics can be studied without a significant Alpine structural overprint.

\section{Geological setting}

The Strandja (Strandhza, Istranca) Massif is a polydeformed, deeply eroded orogenic belt cropping out in a W-E direction in NW Turkey and SE Bulgaria over a distance of about $230 \mathrm{~km}$ and a width of about $60 \mathrm{~km}$ (Figure 1). Its internal structure results from the superposed effects of the Variscan, Cimmerian, and Alpine orogenic cycles (Okay et al. 2001; Lilov et al. 2004; Gerdjikov et al. 2005; Elmas et al. 2011; Sunal et al. 2011; Natal'in et al. 2012; Şahin et al. 2013; Machev et al. 2015). To the north, the Strandja Massif is thrust over the volcanics/volcaniclastics of the Late Cretaceous Eastern Srednogorie extensional basin (Georgiev et al. 2001; Stampfli et al. 2001) (Figure 2). The Western Black Sea fault, a NS-trending dextral strike-slip fault, which originated in the Cretaceous (Okay et al. 1994), defines the eastern boundary of the massif, separating it from the Western Black Sea basin and from the İstanbul exotic terrane (Figure 1). To the south, the thick Eocene-topresent sediments of the Thrace Basin lie non-conformably over the metamorphic rocks of the Strandja Massif
(Turgut et al. 1991; Less et al. 2011) (Figure 2). The western Strandja has been interpreted as thrust over the Eastern Rhodope Massif to the west (Papanikolaou et al. 2004) but the contact is covered by the sediments of the northwestern propagation of the Thrace Basin.

Despite several studies tackling the stratigraphy and structure of the Strandja Massif (e.g. Aydın 1974; Chatalov 1980, 1988, 1990, 1982; Gocev 1985; Dabovski and Savov 1988; Çağlayan 1996; Çağlayan and Yurtsever 1998; Okay et al. 2001; Dabovski et al. 2002; Gerdjikov 2005; Vasilev and Dabovski 2010; Natal'in et al. 2012, 2016), structural correlations and age attributions are still uncertain. An integrated, supranational overview of the Strandja Massif as a whole has been hindered by the scarce colla-boration among the researchers from the two neighbour-ing countries. Most previous studies, often in native language, focus on either the Turkish or the Bulgarian side, ultimately preventing correlation between units and structures. Official maps published by the Committee of Geology and Mineral Resources (Sofia) and the General Directorate of Mineral Research and Exploration (MTA, Ankara) do not match across the border. Limited bilateral mapping and correlation by Bedı et al. (2013) somewhat improved the situation but as of today there is still no consensus as to the overall stratigraphy, structural arrangement, and palaeogeographic interpretation of the massif. Our geological sketch map (Figure 3) and cross-section (Figure 4) is modified after Okay et al. (2001), Sunal et al. (2006), Natal'in et al. (2012) for the Turkish side and based on Chatalov et al. (1995) for the Bulgarian side, with few modifications. More detailed explanations about the petrography and the stratigraphy of the units are provided in those works.

The overall structure of the massif has been traditionally interpreted as a Palaeozoic basement intruded by Permian granitoids and overlain by a Permo-Jurassic metasedimentary cover deposited in an amagmatic epicontinental basin (Aydin 1974, 1982; Çağlayan and 

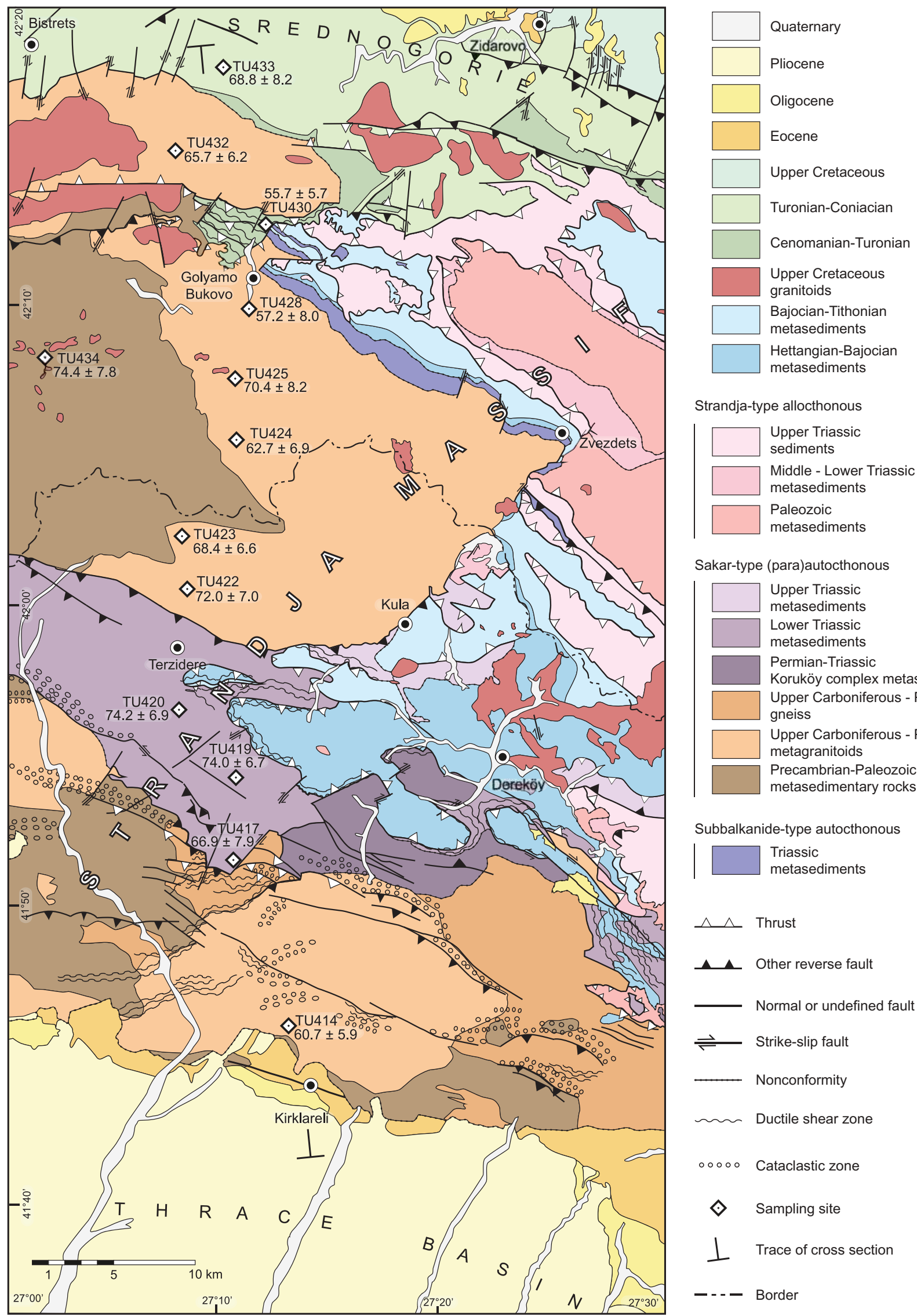

Strandja-type allocthonous

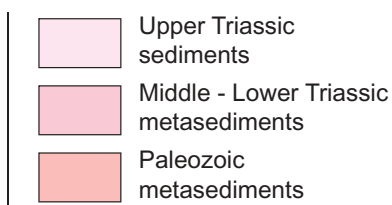

Sakar-type (para)autocthonous

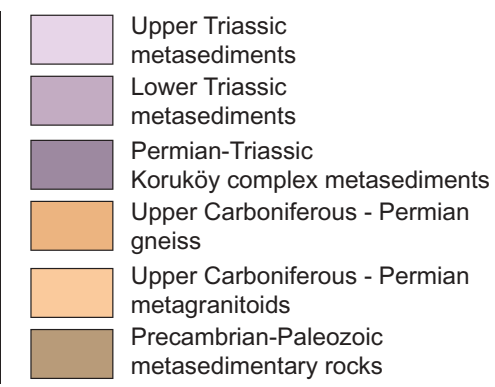

Subbalkanide-type autocthonous

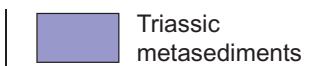

$\triangle \wedge$ Thrust

$\Lambda$ O Other reverse fault

_ Normal or undefined fault

$\rightleftharpoons \quad$ Strike-slip fault

Nonconformity

Ductile shear zone

00000 Cataclastic zone

$\diamond \quad$ Sampling site

$\perp$ Trace of cross section

--- Border

Figure 3. Geological map of the study area, modified after Chatalov et al. (1995), Çağlayan and Yurtsever (1998), Okay et al. (2001), Sunal et al. (2006), Natal'in et al. (2012), and Bedı et al. (2013). Diamonds indicate sample sites, numbers, and apatite fission-track mean ages in $\mathrm{Ma} \pm 1$ standard deviation from the mean. 


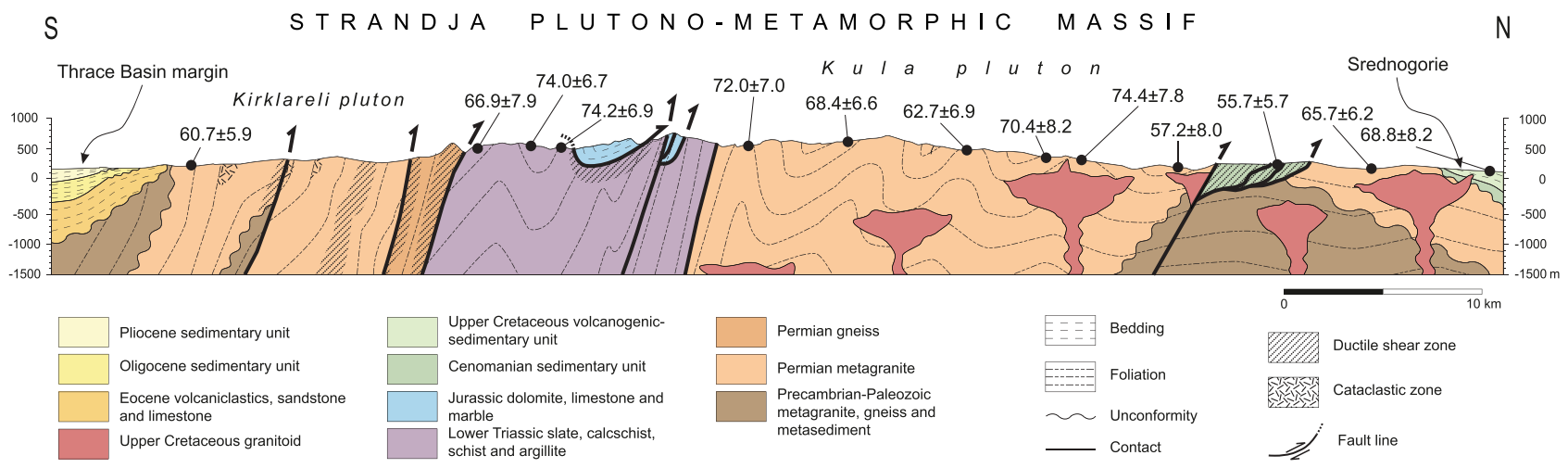

Figure 4. Geological cross-section of the Strandja Massif (see Figure 3 for the location of the trace of the section). Numbers in ellipses are apatite fission-track mean ages in $\mathrm{Ma} \pm 1$ standard deviation from the mean. Modified after Natal'in et al. (2012).

Yurtsever 1998; Okay et al. 2001). More recent studies have proved that the oldest rocks of the Strandja Massif are Precambrian (e.g. Lilov et al. 2004; Şahin et al. 2014; Natal'in et al. 2016).

The older tectonic history of the massif is loosely constrained due to intense Cimmerian-age structural overprint. Nonetheless, several studies locate the Strandja Massif along the northern margin of Gondwana in Late Proterozoic-Early Cambrian times (Yanev et al. 2006; Sunal et al. 2008; Şahin et al. 2014). A number of continental blocks rifted from Gondwana during the Devonian and drifted towards Eurasia (Stampfli and Borel 2002). Collision of these blocks and their accretion along the southern Eurasian margin took place during the Middle-to-Late Carboniferous with the development of the central European Variscan belt of which the Strandja Massif arguably represents the eastern continuation (Okay et al. 2001). A widespread episode of magmatism occurred in the Late Permian (Okay et al. 2001; Sunal et al. 2006) with the emplacement of the Kırklareli-type plutons along a subduction-related magmatic arc (Sunal et al. 2006; Natal'in et al. 2012).

A latest Permian-Jurassic sedimentary succession was deposited on the Variscan basement complex along the northern margin of the Palaeotethys (Chatalov 1990; Stampfli and Hochard 2009). The Triassic succession shows affinities to the central European Germanic facies, with a basal continental clastic series overlain by Middle Triassic shallow-marine carbonates (Chatalov 1988, 1990). On the other hand, in the so-called Strandja-type allochthonous tectonic units (Figure 3), the Triassic is deep marine (Chatalov 1988, 1990; Zagorchev and Budurov 1997; Dabovski et al. 2002; Tchoumatchenco and Tronkov 2010). Marine sedimentation continued into the mid-Jurassic (Bathonian), and came to an end in the Late Jurassic, when the continuing opening of the Izmir-Ankara ocean to the south - forcing the Sakarya zone northward - led eventually to continental collision and thick-skinned thrusts imbrication (Stampfli and Hochard 2009). Ensuing regional metamorphism was of lower amphibolite and greenschist facies but locally the Variscan basement and its covers were brought at depths $>20 \mathrm{~km}$ (Okay et al. 2001). The northward vergence of the nappes and the absence of Late Jurassic-Early Cretaceous back-arc magmatism in the area corroborate the idea of a Rhodope-Strandja passive margin involved in the S-dipping subduction of Küre oceanic crust under the Sakarya terrane, followed by continent-continent collision (Figure 5(a,b)).

The non-metamorphic Late Cretaceous volcano-sedimentary cover of the Srednogorie Zone overlies with an angular unconformity the older units all along the northern margin of the Strandja Massif, providing a Cenomanian minimum age limit for the mid-Mesozoic regional metamorphism. This cover is widespread in Bulgaria (Vâršilo, Grudovo, and Mičurin groups) and crops out more sparsely in Turkey (Iğneada Group), outside the study area (e.g. Okay et al. 2001). The volcano-sedimentary succession sequence as well as all older units are intruded by scattered Late SantonianCampanian biotite- and hornblende-bearing granodiorite stocks (Dereköy-Demirköy granite).

The Cenozoic sediments of the Thrace Basin lap on the eroded metamorphic basement along the southern limb of the Strandja Massif (Figures 2 and 3). The sequence starts with Upper Eocene basal medium-tocoarse conglomerate and sandstone on the margin of the basin, switching to fine-to-medium sandstone interbedded with shale moving towards the centre, topped by a partly dolomitized reef complex (Less et al. 2011). These sediments are overlain by Oligocene marls interbedded with tuff and followed upsection by shale, micritic limestone, and tuff, switching gradationally to fine-to-medium sandstone intercalated with shale and 

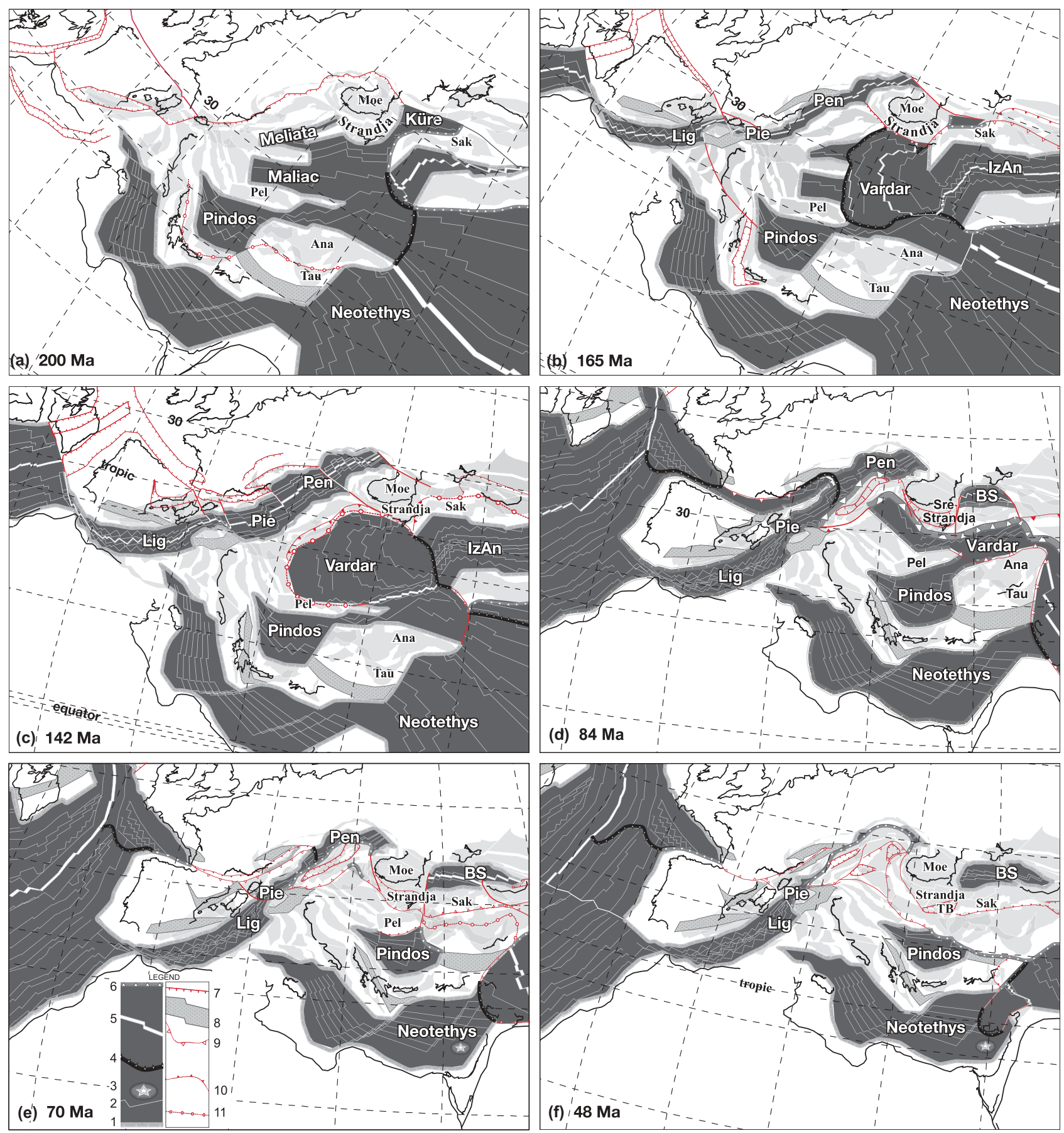

Figure 5. Palaeostructural/palaeoenvironmental reconstructions of the western Tethyan region from the earliest Jurassic (200 Ma) to the Early Eocene (48 Ma) (modified after Stampfli and Hochard 2009). Symbols: 1: passive margins; 2: magmatic or synthetic anomaly; 3: seamount; 4: intraoceanic subduction; 5: mid-ocean ridge; 6: active margin; 7: active rift; 8: inactive rift (basin); 9: collision zone; 10: thrust; 11: suture. Ana: Anatolides; BS: Black Sea; IzAn: İzmir-Ankara ocean; Lig: Ligurian ocean; Moe: Moesia; Pel: Pelagonia; Pen: Penninic; Pie: Piedmont; Sak: Sakarya; Sre: Srednogorie; Tau: Taurus; TB: Thrace Basin.

thin lignite layers and lacustrine claystone and siltstone (Çağlayan and Yurtsever 1998).

From a structural viewpoint, the Strandja Massif can be broadly defined as a metamorphosed, north-verging imbricated orogenic belt (Figures 2-4) made of a polydeformed Variscan basement and its Late Permian-to-
Jurassic cover. The massif was then deeply eroded in Early Cretaceous time and intruded in the Late Cretaceous (Okay et al. 2001; Gerdjikov 2005; Elmas et al. 2011; Natal'in et al. 2012; Şahin et al. 2014; Machev et al. 2015). Pre-Cretaceous units were metamorphosed into greenschist to low-grade amphibolite 
facies during Late Jurassic-Early Cretaceous times (Aydın 1982; Okay et al. 2001; Lilov et al. 2004; Sunal et al. 2011). Peak-metamorphism reached temperatures ranging between $\sim 500^{\circ} \mathrm{C}$ in the south (Sunal et al. 2011) and $\sim 400^{\circ}$ $C$ in the north (Lilov et al. 2004). The Palaeozoic basement complex as well as the Permo-Jurassic metasedimentary cover display a strong, pene-trative SW-dipping foliation reworking all previous structures (Figure 4), in addition to a stretching linea-tion displaying top-to-north, northwest, or northeast sense of shear (Sunal et al. 2006, 2008; Natal'in et al. 2012, 2016). This foliation is late Middle Jurassic-Early Cretaceous (Natal'in et al. 2012; Sunal et al. 2011) and it is consistent with a phase of thick-skinned deformation, nappe imbrication, and metamorphism.

\section{Methods}

\section{Apatite fission-track analysis and modelling}

Fission tracks are radiation damages within the crystal lattice, caused by nuclear fission of radioactive isotope

${ }^{238} \mathrm{U}$ that can be etched and counted under an optical microscope. Concurrently, neutron irradiation is employed to induce the decay of ${ }^{235} \mathrm{U}$, eliciting radia-tion damages on the surface of an external detector. Grain-bygrain determination of both spontaneous and induced fission-track densities yields a single-grain age representing the cooling of the grain below a closure temperature of $\sim 100^{\circ} \mathrm{C}$. Fission-track dating is a useful tool to unravel the cooling histories experienced by rocks in the upper crustal levels and to give a measure of their exhumation (for a review of the method, see Donelick et al. 2005). Fission tracks in apatites all have the same initial length of about $16 \mu \mathrm{m}$ (the specific length depending on composition; e.g. Ketcham et al. 1999) but anneal at rates proportional to temperatures, starting from about $60^{\circ} \mathrm{C}$. Over geological time periods, partial annealing of fission tracks occurs at tempera-tures between about $60^{\circ} \mathrm{C}$ and $125^{\circ} \mathrm{C}$ (i.e. the partial-annealing zone: PAZ; Gleadow and Fitzgerald 1987). Because tracks shorten in relation to the degree and duration of heating, the measurement of fission track lengths gives information about the thermal evolution in the PAZ temperature range. A quantitative evalua-tion of the thermal history can be carried out through modelling procedures, which find a range of cooling paths compatible with the AFT data (Ketcham 2005). In this work, inverse modelling of track length data was performed using the HeFTy program (Ehlers et al. 2005), which generates the possible $T-t$ paths by a Monte Carlo algorithm. Predicted AFT data were calculated according to the Ketcham et al. (2007) annealing model for fission tracks revealed by etching. $D_{\text {par }}$ values (i.e. the etch pit length) were used to define the annealing kinetic parameters of the grains and the original track length.

\section{Sampling strategy and sample preparation}

Twenty-one samples were taken from the metamorphosed late-Variscan intrusives and Triassic sedimentary cover of the massif, and from the Late Cretaceous volcaniclastics and granitoid intrusions (Table 1). The samples were collected along a $\mathrm{N}-\mathrm{S}$ transect (see Figures 3 and 4 for the exact location) perpendicular to the strike of the main tectonic structures. Apatite grains were concentrated by crushing and sieving, followed by hydrodynamic, magnetic, and heavy-liquid separation. Apatites were embedded in epoxy resin, polished in order to expose the internal surfaces within the grains, and the spontaneous FT were revealed by etching with $5 \mathrm{~N} \mathrm{HNO}_{3}$ at $20^{\circ} \mathrm{C}$ for 20 s. The mounts were then coupled with a low-uranium fission-track-free muscovite mica sheet (external detector method) and sent for irradiation with thermal neutrons (see Donelick et al. 2005, for details) at the Radiation Center of Oregon State University. Nominal fluence of $9 \times 10^{15} \mathrm{n} \mathrm{cm} \quad 2$ was monitored with a CN5 uranium-doped silicate glass dosimeter. Induced fission tracks were revealed by etching of the mica sheets in $40 \% \mathrm{HF}$ for $45 \mathrm{~min}$ at $20^{\circ} \mathrm{C}$. Spontaneous and induced fission tracks were counted under optical microscope at 1250x magnification, using an automatic stage (FTStage sys-tem) plus a digitizing tablet.

Central ages were calculated with the zeta calibration approach (Hurford and Green 1983), using Durango (31.3 $\pm 0.3 \mathrm{Ma})$ and Fish Canyon Tuff $(27.8 \pm 0.2 \mathrm{Ma})$ age standards within grains exposing $c$-axis-parallel crystallographic planes. Thirteen samples of the original set yielded suitable apatites. Track-length distributions were calculated by measuring horizontal confined tracks together with the angle between the track and the $c$-axis. Confined tracks constitute a small part of the FT population, therefore additional concentrates were mounted, polished, and etched for the analysis. Ultimately, eight samples contained a statistically significant number of confined tracks.

\section{Geological constraints for thermochronometric modelling}

All available geological constraints (intrusion ages, metamorphic events, depositional ages, and stratigraphic relationships) were incorporated into the modelling. The intrusion age of the Kırklareli and Kula 


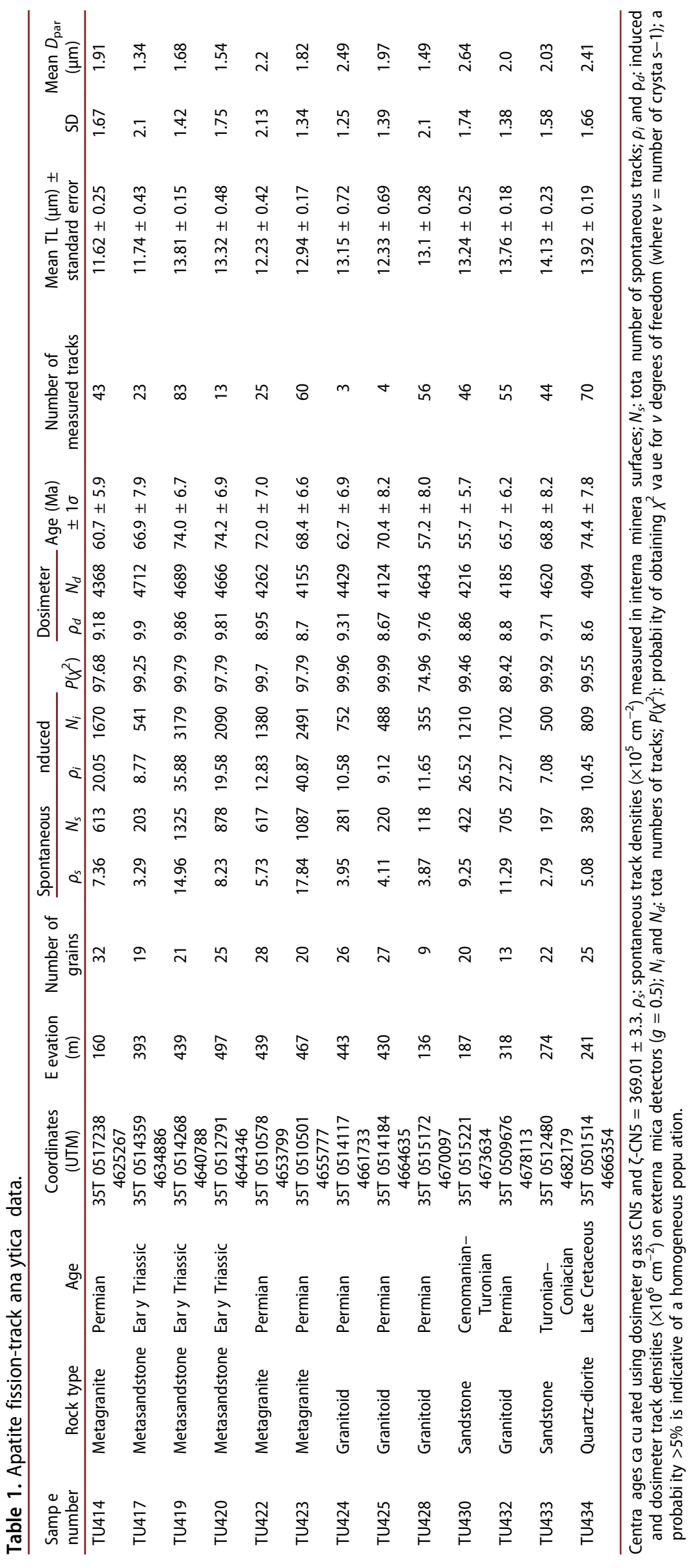


metagranites (samples TU414, TU423, TU428, TU432) is $\sim 271 \mathrm{Ma}$ (Okay et al. 2001), while their temperature of emplacement was between $750^{\circ} \mathrm{C}$ and $850^{\circ} \mathrm{C}$ (Miller et al. 2003). Triassic metasandstones (e.g. sample TU419) are Olenekian-Induan in age (Evciler Formation in Bedı et al. 2013). By extension, we assumed wide-spread Early Triassic subaerial/shallow-marine sedimen-tation above the Permian granitoids, implying that in OlenekianInduan times samples TU414, TU423, TU428, TU432 were also near the surface $\left(\sim 20^{\circ} \mathrm{C}\right)$. Sunal et al.(2011) constrained the peak of Late Jurassic-Early Cretaceous regional metamorphism in the Turkish part of the Strandja Massif between $162.3 \pm 1.6$ and $157.7 \pm 1.5 \mathrm{Ma}$ with progressively younger cooling ages from south to north. Estimated temperature con-ditions reached 485$530^{\circ} \mathrm{C}$ in the south and $450-500^{\circ} \mathrm{C}$ in the northern part (within epidote-amphibolite facies conditions). As to the Bulgarian part, Lilov et al. (2004) proposed a peak of regional greenschist-facies meta-morphism at 160-170 $\mathrm{Ma}$, with temperatures ranging between $350^{\circ} \mathrm{C}$ and $450^{\circ}$ C.

Depositional ages of Late Cretaceous sedimentary rocks, namely the Vârsilo (TU430) and Grudovo groups (TU433) are reckoned as Cenomanian-Turonian and Turonian-Coniacian, respectively (Chatalov et al. 1995). We considered that those samples were in subaerial conditions $\left(\sim 20^{\circ} \mathrm{C}\right)$ alongside sample TU432 from the underlying Permian bedrock being eroded. Finally, the Permian metagranite cropping out along the margin of the Thrace Basin is non-conformably overlain by Late Bartonian to Oligocene basal conglomerate, sandstone, and limestone (Less et al. 2011), thus implying that sample TU414 was near the surface $\left(\sim 20^{\circ} \mathrm{C}\right)$ during that time.

\section{Analytical results}

Table 1 and Figure 6 provide a summary of the AFT data. Central ages range from $74.4 \pm 7.8$ to $55.7 \pm 5.7 \mathrm{Ma}$ (Late Campanian-Early Ypresian), without any particular geographic trend or age-elevation corre-lation. All the samples passed the $X^{2}$ test indicating a single population of grains. Such central ages could be mistaken as evidence of an Alpine phase of cooling/exhumation, but the results of thermochronometric modelling based on statistical analysis of fission-track length distributions indicate slow cooling throughout the Late Cretaceous and the Palaeocene for most sam-ples (Figure 7). In such a case, central ages are not significant and only the statistical modelling of fission-track length distributions can constrain the $T-t$ paths, as discussed below.
The southernmost sample TU414 is a late Palaeozoic metagranite from the Kırklareli pluton (Figures 3 and 4, Table 1). Its bimodal track-length distribution indicates that sample TU414 underwent a complex thermal history. Inverse modelling best-fit path shows rapid cooling through the PAZ between 145 and $138 \mathrm{Ma}$ (earliest Cretaceous; Figure 7), followed by a long period at nearsurface conditions. In the Late Oligocene, a new episode of moderate heating brought the sample back in the PAZ, followed by Neogene cooling.

Moving northward, sample TU417 (Early Triassic metasandstone) also yielded an earliest Cretaceous central age, similar to sample TU414. This sample did not contain enough confined FT for inverse modelling. Sample TU419 (Early Triassic metasandstone) yielded a tight cluster of single-grain ages (80-70 Ma), a central age of $74.0 \pm 6.7 \mathrm{Ma}$, and a leptokurtic track-length distribution with a single peak and relatively long mean track length of $13.81 \pm 0.15 \mu \mathrm{m}$. The best-fit $t-T$ path shows slow cooling through the PAZ between ca. 105 and $65 \mathrm{Ma}$ (Figure 7). Both samples TU420 (Triassic metasandstone) and TU422 (metagranite) did not contain enough confined tracks for inverse modelling.

Sample TU423 (metagranite; Kula pluton) yielded relatively broad single-grain age and track-length distributions. The modelling indicates extremely slow cooling through the PAZ from ca. 110 to $30 \mathrm{Ma}$ (Figure 7). Samples TU424 and TU425 are also from the Kula plu-ton and are both characterized by the virtual absence of confined tracks, hindering inverse modelling. Sample TU434 was taken from a Santonian granitic intrusion (Aydın 1982) $\sim 10 \mathrm{~km}$ west of the transect line. It yielded the oldest AFT central age of the set $(74.4 \pm 7.8 \mathrm{Ma})$ and displayed relatively long confined tracks (mean track length $=13.92 \pm 0.19 \mu \mathrm{m}$ ). In accordance with the overall trend, slow cooling within the PAZ occurred between 95 and $50 \mathrm{Ma}$, with an acceleration in the cooling rate at $\sim 50 \mathrm{Ma}$ (Figure 7).

Sample TU428 (Permian metagranite in the northern part of the Kula pluton) is characterized by a platykurtic (and bimodal) track-length frequency distribution (Figure 6). Inverse modelling of this sample describes a very slow cooling and a long residence time within the PAZ (Figure 7), with an acceleration in the cooling rate since the mid-Eocene (from $\sim 40 \mathrm{Ma}$ ). Sample TU430 was collected from a mélange derived from tectonic disruption of Cenomanian sandstone in the footwall of a major north-verging nappe (Figures 3 and 4). This sample yielded a broad track-length distribution with two scarcely distinguishable peaks. Inverse modelling indicates slow heating from surficial conditions at about $95 \mathrm{Ma}$ (depositional age), entering the $60^{\circ} \mathrm{C}$ isotherm at $70 \mathrm{Ma}$, maximum heating $\left(\sim 110^{\circ} \mathrm{C}\right)$ at 

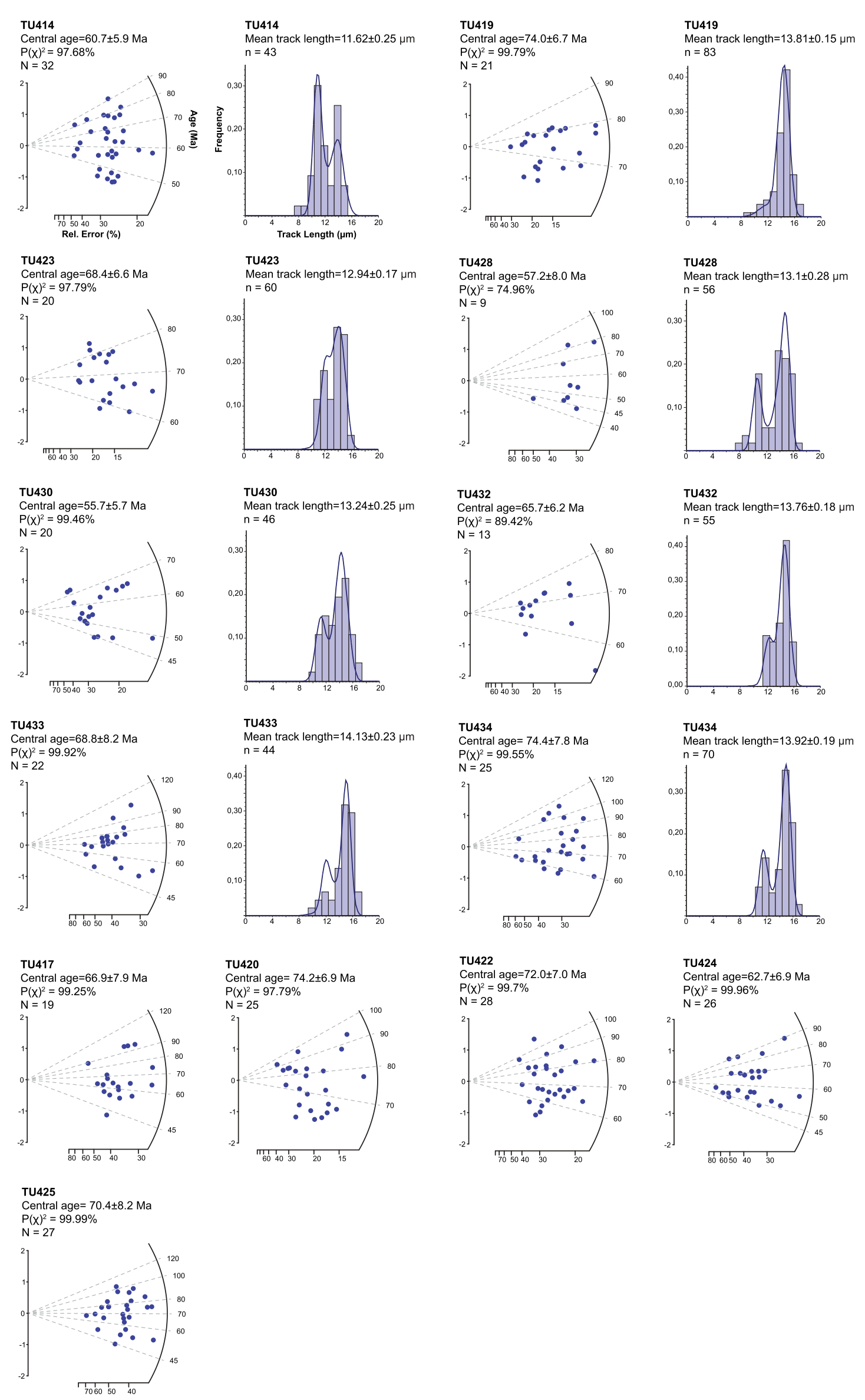

Figure 6. Radial plots of single-grain apatite fission-track ages. Histograms show the confined-track length distributions of the eight samples whose time-temperature paths are shown in Figure 7. 

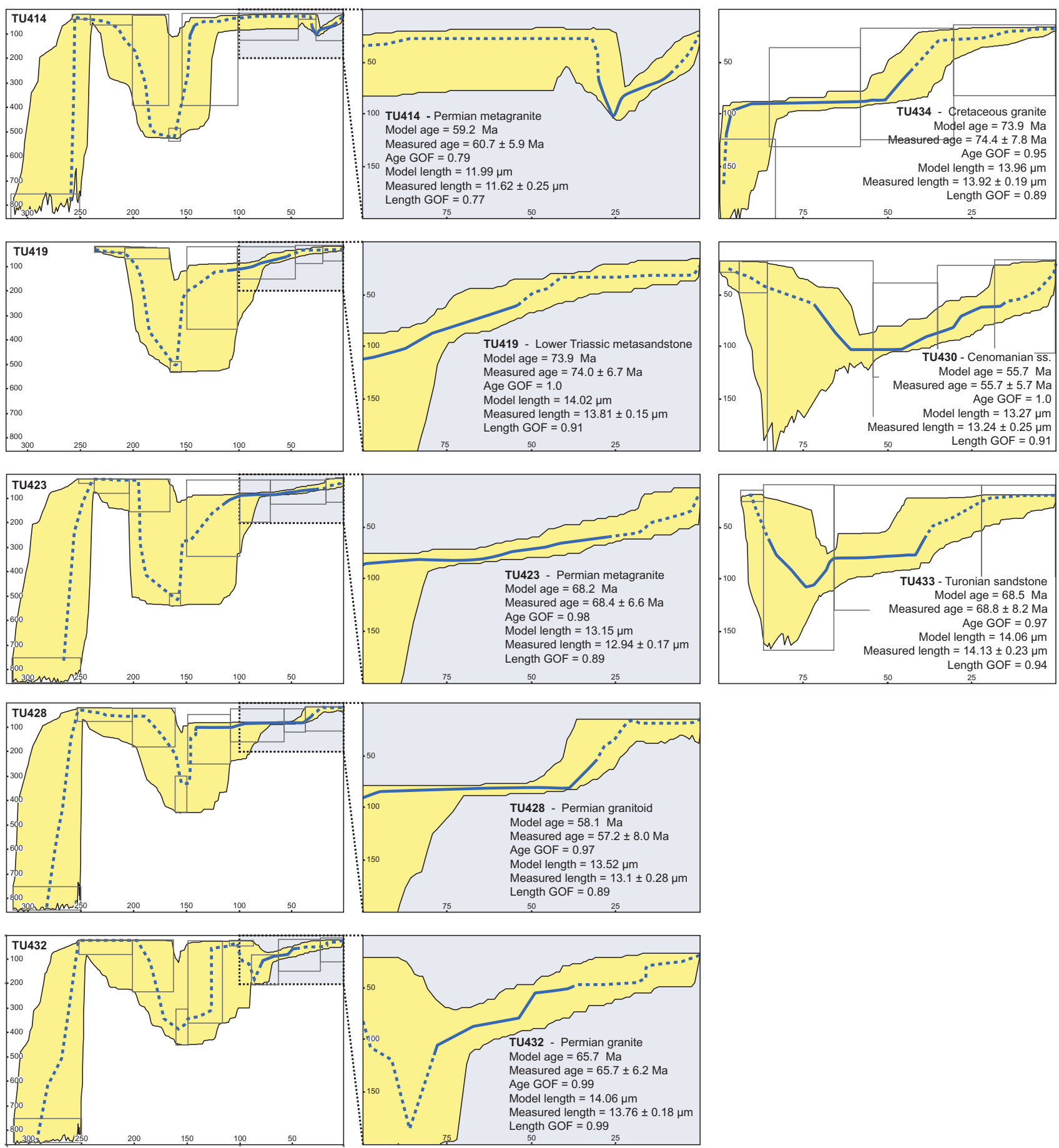

Figure 7. Time-temperature paths obtained from inverse modelling of apatite fission-track data. Graphs in the central column are enlargements of portions of those to the left. $X$-axes and $Y$-axes of all diagrams refer to age (Ma) and temperature $\left({ }^{\circ} \mathrm{C}\right)$, respectively. Yellow areas mark envelopes of statistically acceptable fit, and the thicker lines correspond to the most probable thermal histories (best-fit curves). Boxes represent $T-t$ domains constrained by available data (radiometric ages, stratigraphic relationships, AFT analyses). Parameters related to inverse modelling are reported: $n$, number of measured track lengths; GOF, goodness-of-fit gives an indication about the fit between observed and predicted data (values closer to 1 are best).

60-45 Ma, followed by progressive cooling (Figure 7). Sample TU430 never suffered temperatures higher than $120^{\circ} \mathrm{C}$ (i.e. the base of the partial annealing zone), nonetheless no single grain-ages older than $75 \mathrm{Ma}$ were determined from this detrital sample, possibly the result of the long residence time within the PAZ and the maximum temperature very close to the $120^{\circ} \mathrm{C}$ isotherm. Alternatively, considering the envelopes of 
statistically acceptable fit in Figure 6, one might conclude that total annealing might have occurred below the bottom of the PAZ.

The two northernmost samples display a fairly similar thermochronometric evolution. Sample TU432 was taken from the northern rim of the Kula pluton, separated from the main body by a thrust fault (Figures 3 and 4), and yielded a unimodal track-length distribution (Figure 6). The thermochronometric modelling constrains two discrete phases of cooling, in the Campanian and in the Middle-Late Eocene (Figure 7). The northernmost sample (TU433) was taken from the Turonian sandstones at the base of the Yambol-Burgas basin fill (Figure 3). The sample yielded a range of single-grain ages, from 110 to $45 \mathrm{Ma}$. Again, two discrete phases of cooling occurred: in the Late Cretaceous and in the Late Eocene (Figure 7). The slight difference in the reconstructed thermochronometric evolution of the two samples may result from their relative position within the north-verging Strandja orogenic wedge, with somewhat higher temperatures and earlier deformation to the south.

\section{Discussion}

The extent of the late stage of the Cimmerian orogenic cycle in the Rhodopes and the Strandja Massif has been a matter of much debate, to the point of being underestimated or ignored altogether in several palaeostructural/palaeoenvironmental reconstructions (e.g. Dercourt et al. 1985, 1993, 2000; Barrier and Vrielynck 2008). In the Strandja massif, geochronological evidences and field observations (Tchoumatchenco et al. 1989; Okay et al. 2001; Lilov et al. 2004; Sunal et al. 2011; Natal'in et al. 2012) contrast with these reconstructions and entail the occurrence of significant shortening - plausibly the result of collision - at the JurassicCretaceous boundary. Such shortening induced thickskinned thrust imbrication and metamorphism in the area. Peak metamorphic temperatures, amount of deformation, and kinematic indicators indicate northward propagation of the orogeny (Okay et al. 2001; Lilov et al. 2004; Sunal et al. 2011). As for the tectonic setting in that period, the Strandja massif underwent an initial condition of passive continental margin along the Eurasian plate, followed by collision with the northwestern end of the Sakarya continental element (Figure 5(b, c)). This event determined the main internal structure of the massif and of the western Pontides as well.

Many uncertainties persist on the geological evolution of the Strandja Massif and its palaeogeographic position through time as the area was affected by multiple deformations during the Variscan, Cimmerian, and Alpine orogenic cycles (Okay et al. 2001; Stampfli et al. 2001; Stampfli and Borel 2002; Stampfli and Kozur 2006; Sunal et al. 2008; Von Raumer and Stampfli 2008; Stampfli and Hochard 2009; Natal'in et al. 2012). Despite the complexities introduced by single geological structures, broad-scale low-temperature thermochronometric patterns provide first-order information on the tectonic processes that cause rock cooling. The AFT analyses presented in this paper place a number of compelling constraints which needs to be integrated in any reconstruction of the tectonic evolution of the Strandja Massif.

In our study area, the integration of available Neocimmerian peak-metamorphic ages/temperatures with our AFT-derived thermochronologic modelling points to a rapid Late Jurassic heating followed by similarly rapid cooling (Figure 7). Integrated thermochronometric modelling shows a slightly diachronous inception of Neocimmerian peak metamorphism from south to north. Following Neocimmerian metamorphism, cooling of the southernmost sample (TU414; Late Permian metagranite from the Kırklareli pluton) across the PAZ is well constrained in the Berriasian. Conversely, samples TU419 and TU423 from the central portion of the massif both entered the PAZ later in the Early Cretaceous. Despite coming from different struc-tural positions (Figures 3 and 4), these two samples display a very similar subsequent thermochronometric evolution, characterized by a long residence time within the PAZ ( $>55 \mathrm{Ma}$ ) during the Late Cretaceous and most of the Palaeogene. Sample TU428 in the Bulgarian por-tion of the massif resembles TU414, with lower tem-perature of metamorphism (Lilov et al. 2004), drastic cooling in Berriasian as well, but never exiting the PAZ.

During the Aptian-Albian rifting began in the western Black Sea back-arc (Zonenshein and Le Pichon 1986; Nikishin et al. 2015) due to progressive southward slab roll-back within the context of continued north-ward subduction of the Vardar-izmir-Ankara oceanic domain underneath the southern Eurasian continental margin. Black Sea extensional tectonics extended west-ward into the Srednogorie zone of central Bulgaria (Figure 5(d)) (Georgiev et al. 2001), where rift-related CenomanianTuronian conglomerate and sandstone overlie nonconformably the basement complex (Figures 3 and 4) and grade upsection into the thick volcano-sedimentary succession of the Yambol--Burgas basin. Continued extension led to the intrusion of a number of shallow latest Cretaceous stocks piercing both the basement complex and its Cretaceous sedi-mentary cover (Georgiev et al. 2012). This thermal event is registered in the northernmost portion of the study area where samples TU432 (Permian granite) and T U433 
(Turonian sandstone) both show a discrete episode of heating in the Campanian, in agreement with available $\mathrm{U}-\mathrm{Pb}$ zircon ages from plutonic rocks of the same region clustering at $\sim 80 \mathrm{Ma}$ (Georgiev et al. 2012). Sample TU434 - taken from a Late Cretaceous shallow intrusion (Figure 3) - resided within the apatite PAZ $\left(\sim 60-120^{\circ} \mathrm{C}\right)$ from the latest Cretaceous until the late Early Eocene when it started to undergo rapid cooling/ exhumation (Figure 7).

North of Golyamo Bukovo in Bulgaria (Figure 3) the basal Cenomanian-Turonian sedimentary rocks suffered intense deformation along a prominent brittle shear zone trending west-east and dipping to the SSW at an angle of about $45^{\circ}$, to become a tectonic mélange. Sample TU430 was taken from the mélange: it shows (i) progressive burial-driven heating during the Late Cretaceous, followed by (ii) permanence at the base of the PAZ in the Palaeocene-Early Eocene, and (iii) progressive cooling/exhumation since the Middle Eocene (Figure 7). From a broader perspective, all samples from the northern part of the study area underwent cooling starting from the late Early-Middle Eocene. This matches an important phase of thrusting in the development of the East Balkan thrust belt (Banks 1997; Sinclair et al. 1997; Stewart et al. 2011). Considering the pervasive Late Jurassic-Early Cretaceous structural fabric of the Strandja Massif, the Golyamo Bukovo and the other major $\mathrm{N}$-verging overthrusts of the northern massif likely have an older Neocimmerian thermal signature which was overprinted and erased by younger deformation.

Immediately south of the study area lies the Thrace Basin, a large Middle Eocene to Quaternary sedimentary basin. Basin-floor geometry features a number of structural highs and deep depocenters; as a consequence the sedimentary fill - reaching a maximum thickness of $9000 \mathrm{~m}$ - is characterized by abrupt lateral variations in thickness and facies types (Turgut and Eseller 2000; Siyako and Huvaz 2007; d'Atri et al. 2012; Cavazza et al. 2013). Limited deep borehole information as well as geophysical data indicate that the floor of the Thrace Basin is made of basement rocks similar to those of the Strandja and Rhodope massifs, which raises the question of the true areal extent of the Cimmerian orogenic wedge to the south. (The same consideration applies for its northern termination, concealed by the volcanosedimentary succession of the Yambol-Burgas basin of the Srednogorie zone.)

The geodynamic setting and structural evolution of the Thrace Basin is far from being understood. Following Görür and Okay (1996), it was long interpreted as a forearc basin which developed in a context of northward subduction. This interpretation was challenged by more recent data emphasizing the lack of both a coeval magmatic arc and a subduction complex associated with the basin (d'Atri et al. 2012; Cavazza et al. 2013). All these elements - along with the correspondence between subsidence pulses in the basin and lithospheric stretching in the metamorphic core complexes of southern Bulgaria and the northern Aegean region - indicate instead that the Thrace Basin was likely the result of post-orogenic collapse after the continental collision related to the closure of the VardarIzmir-Ankara ocean in the latest Cretaceous (Figure 5(e)). The role of the structural inversion of preexisting Cimmerian structures in the development of the basin should also be considered.

Our thermochronometric transect across the Strandja Massif spans the transition between a region of Eocene compression (i.e. the eastern Balkans) to the north and a region of marked Eocene subsidence (the Thrace Basin) to the south (Figure 2). The AFT dataset presented in this paper records such transition. Late Early-Middle Eocene contraction was thermochronologically recorded only in the northern part of the Strandja Massif. As discussed above, all northern samples show a phase of contractional cooling/exhumation during the Eocene. Conversely, irrespective of their lithologic nature, the samples from the central and southern portions of the massif underwent slow erosional cooling throughout the Cenozoic (Figure 7). The southernmost sample (TU414; Figure 3), a Palaeozoic metagranite along the northern margin of the Thrace Basin, is the only sample in the entire dataset showing a phase of heating in the Oligocene (Figure 7), the result of regional basinal subsidence and progressive sediment burial. This sample was then exhumed during the Neogene, possibly due to the activity of a complex array of blind strike-slip faults forming the main present-day boundary between the outcropping portion of the Strandja Massif and the Thrace Basin (Perinçek 1991; Turgut et al. 1991).

Alpine-age orogenic events in the Balkan peninsula are related to the successive closures of the Vardar (latest Cretaceous) and Pindos (Middle-Late Eocene) oceans and the associated accretion of the Pelagonian and Greater Apulia continental blocks along the southern Eurasian margin (Stampfli and Hochard 2009) (Figure 5). The Cimmerian orogenic wedge of the Strandja Massif has not registered these events in terms of low-temperature thermochronology as our AFT analyses and modelling from the main body of the massif do not show any significant thermal event coeval with these collisional orogenies. Most Alpine-age deformation focused instead to the north, with the development of the thin-skinned thrust belt of the 
Eastern Balkans and coeval widespread syntectonic deposition within a foreland basin (e.g. Nachev 1981; Doglioni et al. 1996; Bergerat et al. 2010; Stewart et al. 2011). Alpine-age deformation focused in the Srednogorie region because it had been rheologically weakened by Late Cretaceous back-arc extension. Other studies described Late Eocene-Miocene inversion structures in various locations along the western Black Sea margin (Doglioni et al. 1996; Stovba et al. 2009). Munteanu et al. (2011) identified a coherent thickskinned thrust system with northward vergence in the Romanian offshore. In this region, thrusting inverted a number of Cretaceous grabens; shortening started during the Late Eocene and affected all areas of the Western Black Sea Basin during Oligocene and Miocene times, gradually migrating northward.

It cannot be excluded that the basement floor of the Thrace Basin was deformed following the closure of the Vardar-İzmir-Ankara oceanic domain before experiencing subsidence from the Middle Eocene due to orogenic collapse induced by slab rollback. In particular, the role of the blind Terzili strike-slip fault system for the geodynamics of the whole southern Balkan region might has been greatly underestimated as such system might represent a long-lived major tectonic contact repeatedly reactivated with different kinematics. Further thermochronological and structural works in the region are needed to clarify these issues.

\section{Conclusions}

This work presents the first low-temperature thermochronology results for the Strandja Massif, based on AFT analysis of Permian, Triassic, and Cretaceous rock samples. Thermal evolution was investigated along a transect extending from the Cenozoic sediments of the Thrace Basin in the south to the Late Cretaceous volcanics/volcaniclastics of the Srednogorie zone in the north. The integration of our new thermochronometric data with radiometric, structural, and stratigraphic data from the literature provides cogent constraints on the geological evolution of the Strandja Massif and the palaeogeographic/palaeotectonic reconstructions of the entire Balkan region.

Following Late Jurassic crustal shortening and regional metamorphism, the central part of the Strandja Massif underwent a Kimmeridgian-Berriasian phase of relatively rapid cooling/exhumation. Conversely, the overall thermal evolution in the massif during the Late Cretaceous is one of slow erosional cooling - possibly driven by erosion - with the exception of its northernmost part which was involved in Srednogorie back-arc rifting. In this region, the intrusion of small plutons at shallow crustal levels (cooling ages of ca. $80 \mathrm{Ma}$; Campanian) reset locally the AFT system, as shown by our thermochrologic modelling. If the local thermal effects of such plutonism are filtered from the models, the entire post-Cimmerian thermochrometric evolution of the Strandja Massif indicates tectonic quiescence from the Late Cretaceous to the Early Eocene. Such tectonic inactivity continued in the central portion of the Strandja Massif, whereas its northern portion and the southern Srednogorie back-arc basin underwent rapid contractional exhumation starting between 50 and $40 \mathrm{Ma}$ (Middle Eocene). Alpine-age stresses related to the closure of the northern branch of Neotethys and the ensuing development of the Vardarİzmir-Ankara suture zone were transmitted over a long distance through the Strandja Cimmerian orogenic wedge and focused preferentially to the north, in the area previously weakened by Srednogorie extensional tectonics.

\section{Acknowledgements}

We thank two anonymous reviewers for their comments which improved the clarity of the manuscript. Thanks to Irene Albino for technical help in the first stages of this research.

\section{Disclosure statement}

No potential conflict of interest was reported by the authors.

\section{Funding}

Funding for this research was provided by the University of Bologna RFO funds.

\section{ORCID}

William Cavazza http://orcid.org/0000-0002-6030-9689

\section{References}

Aydin, Y., 1974, Etude petrographique et geochimique de la partie centrale du Massif d'Istranca (Turquie). PhD dissertation, University of Nancy, 131 pp. [in French].

Aydın, Y., 1982, Geology of the Yıldız Mountains (Istranca)

massif. Istanbul Technical University Engineering and Architecture Faculty, Associate Professor Thesis [in Turkish].

Banks, C.J., 1997, Basins and thrust belts of the Balkan coast and the Black Sea, in Robinson, A.G., Ed., Regional and petroleum geology of the Black Sea and surrounding region: AAPG Memoir 68: p. 115-128.

Barrier, E., Vrielynck, B., Bergerat, F., Brunet, M.F., Mosar, J., Poisson, A., and Sosson, M., 2008, Palaeotectonic maps of the Middle East: Tectono-sedimentary-palinspastic maps from Late Norian to Pliocene. MEBE Project. 
Bedı, Y., Vasilev, E., Dabovski, C., Ergen, A., Okuyucu, C., Doğan, A., Tekin, U., Ivanova, D., Boncheva, I., Lakova, I., Sachanski, V., Kuşcu, I., Tuncay, E., Demiray, G., Soycan, H., and Göncüoğlu, M.C., 2013, New age data from the tectonostratigraphic units of the Istranca "Massif" in NW Turkey: A correlation with SE Bulgaria: Geologica Carpathica, v. 64, p. 255-277. 10.2478/geoca-2013-0019

Bergerat, F., Vangelov, D., and Dimov, D., 2010, Brittle deformation, paleostress field reconstruction and tectonic evolution of the Eastern Balkanides (Bulgaria) during Mesozoic and Cenozoic times: Geological Society London Special Publication, v. 340, p. 77-111. 10.1144/SP340.6

Burchfiel, B.C., and Nakov, R., 2015, The multiply deformed foreland fold-thrust belt of the Balkan orogen, northern Bulgaria: Geosphere, v. 11(2), p. 463-490. 10.1130/ GES01020.1

Çağlayan, M.A., 1996, Evolution of Strandja Massif in Mesozoic-Lower Tertiary and its role in the evolution of Thrace Basin: Bulletin Turkish Association Petrol Geological, v. 81, p. 82-93.

Çağlayan, M.A., and Yurtsever, A., 1998, Geological Map of Turkey 1:100,000 scale, no. 20, 21, 22, 23, Burgaz-A3, Edirne-B2 and B3, Burgaz-A4 and Kırklareli-B4; Kırklareli-B5 and B6; Kırklareli-C6 Sheets: Ankara, Mineral Research and Exploration Institute (MTA) of Turkey.

Cavazza, W., Caracciolo, L., Critelli, S., d'Atri, A., and Zuffa, G.G., 2013, Petrostratigraphic evolution of the Thrace Basin (Bulgaria, Greece, Turkey) within the context of EoceneOligocene post-collisional evolution of the Vardar-İzmirAnkara suture zone: Geodinamica Acta, v. 26(1-2), p. 1226. 10.1080/09853111.2013.858943

Cavazza, W., Roure, F., and Ziegler, P.A., 2004, The Mediterranean area and the surrounding regions: Active processes, remnants of former Tethyan oceans and related thrustbelts, in Cavazza, W., Roure, F., Spakman, W., Stampfli, G.M., and Ziegler, P.A., eds., The TRANSMED Atlas: The Mediterranean Region from Crust to Mantle: Heidelberg, Springer-Verlag, p. 1-29.

Chatalov, G., 1990, Geology of the Strandja zone in Bulgaria: Sofia Publishing House Bulgarian Academy of Sciences, p. $1-263$.

Chatalov, G., Dabovski, C., Savov, S., Filipov, L., Nikolov, G., and Aneva, T., 1995, Zeljazkovo sheet, 1:100,000 scale Geological Map of Bulgaria: Sofia, Committee of Geology and Mineral Resources.

Chatalov, G.A., 1980, Two facies type of Triassic in Strandza mountain, SE Bulgaria: Rivista Italiana Paleontologia, v. 85, p. $1029-1046$.

Chatalov, G.A., 1988, Recent developments in geology of the Strandzha zone in Bulgaria: Bulletin Technical University Istanbul, v. 41, p. 433-465. [in Turkish].

d'Atri, A., Zuffa, G.G., Cavazza, W., Okay, A.I., and Di Vincenzo, G., 2012, Detrital supply from subduction/accretion complexes to the Eocene-Oligocene post-collisional southern Thrace Basin (NW Turkey and NE Greece): Sedimentary Geology, v. 243-244, p. 117-129. 10.1016/j. sedgeo.2011.10.008

Dabovski, C., Boyanov, I., Zagorchev, I., Nikolov, T., Sapunov, I., Khrischev, K., and Yanev, Y., 2002, Structure and Alpine evolu-tion of Bulgaria: Geologica Balcanica, v. 32(2/4), p. 916.
Dabovski, C., and Savov, S.S., 1988, Structural studies in the nappes of Southeast Strandza: Geologica Balcanica, v. 18, p. 19-36.

Dercourt, J., Gaetani, M., Vrielynck, B., Barrier, E., Biju-Duval, B., Brunet, M.F., Cadet, J.P., Crasquin, S., and Sandulescu, M., 2000, Atlas Peri-Tethys Palaeogeographical Maps: Paris, Commission de la Carte Géologique du Monde.

Dercourt, J., Ricou, L.E., and Vrielynck, B., 1993, Atlas Tethys palaeoenvironmental maps: Paris, Gauthier-Villars.

Dercourt, J., Zonenshain, L.P., Ricou, L.E., Kazmin, V.G., Le Pichon, X., Knipper, A.L., Grandjacquet, C., Sborshchikov, I. M., Boulin, J., Sorokhtin, O., Geyssant, J., Lepvrier, C., BijuDuval, B., Sibuet, J.-C., Savostin, L.A., Westphal, M., and Lauer, J.-P., 1985, Presentation de 9 cartes paleogeographiques au 1/2,000,000 s' etendant de I'Atlantique au Pamir pour la periode du Lias a l'Actuel: Bulletin De La Société Géologique De France, v. 1(5), p. 637-652.

Doglioni, C., Busatta, C., Bolis, G., Mariannini, L., and Zanella, M., 1996, Structural evolution of the Eastern Balkans (Bulgaria): Marine and Petroleum Geology, v. 13(2), p. 225-251. 10.1016/0264-8172(95)00045-3

Donelick, R.A., O'Sullivan, P.B., and Ketcham, R.A., 2005, Apatite fission-track analysis: Reviews in Mineralogy and Geochemistry, v. 58(1), p. 49-94. 10.2138/rmg.2005.58.3

Ehlers, T.A., Chaudhri, T., Kumar, S., Fuller, C.W., Willett, S.D., Ketcham, R.A., Brandon, M.T., Belton, D.X., Kohn, B.P., Gleadow, A.J., and Dunai, T.J., 2005, Computational tools for low-temperature thermochronometer interpretation: Reviews in Mineralogy and Geochemistry, v. 58(1), p. 589622. 10.2138/rmg.2005.58.22

Elmas, A., Yılmaz, I., Yiğitbaş, E., and Ullrich, T., 2011, A Late Jurassic-Early Cretaceous metamorphic core complex, Strandja Massif, NW Turkey: International Journal of Earth Sciences, v. 100(6), p. 1251-1263. 10.1007/ s00531-010-0540-3

Georgiev, G., Dabovski, C., and Stanisheva-Vassileva, G., 2001, East Srednogorie-Balkan Rift Zone, in Ziegler, P.A., Cavazza, W. Robertson, A.H.F., and Crasquin-Soleau, S., eds., Peritethyan Rift/Wrench Basins and Passive Margins: Paris, Mémoires du Muséum National d'Histoire Naturelle, v. 186, p. 259-293.

Georgiev, S., Von Quadt, A., Heinrich, C.A., Peytcheva, I., and Marchev, P., 2012, Time evolution of a rifted continental arc: Integrated ID-TIMS and LA-ICPMS study of magmatic zircons from the Eastern Srednogorie, Bulgaria: Lithos, v. 154, p. 53-67. 10.1016/j.lithos.2012.06.020

Gerdjikov, I., 2005, Alpine metamorphism and granitoid magmatism in the Strandja zone: New data from the Sakar unit, SE Bulgaria: Turkish Journal of Earth Sciences, v. 14(2), p. 167-183.

Gleadow, A.J.W., and Fitzgerald, P.G., 1987, Uplift history and structure of the Transantarctic Mountains: New evidence from fission track dating of basement apatites in the Dry Valleys area, southern Victoria Land: Earth and Planetary Science Letters, v. 82, p. 1-14. 10.1016/0012-821X(87) 90102-6

Gocev, P.M., 1985, Strandzides: Geotectonics, Tectonophysics and Geodynamics, v. 18, p. 28-54.

Görür, N., and Okay, A.I., 1996, A fore-arc origin for the Thrace Basin, NW Turkey: Geologische Rundschau, v. 85, p. 662-668. 10.1007/BF02440103 
Hurford, A.J., and Green, P.F., 1983, The zeta age calibration of fission-track dating: Chemical Geology, v. 41, p. 285-317. 10.1016/S0009-2541(83)80026-6

Ketcham, R.A., 2005, Forward and inverse modeling of lowtemperature thermochronometry data: Reviews in Mineralogy and Geochemistry, v. 58(1), p. 275-314. 10.2138/rmg.2005.58.11

Ketcham, R.A., Carter, A., Donelick, R.A., Barbarand, J., and Hurford, A.J., 2007, Improved modeling of fission-track annealing in apatite: American Mineralogist, v. 92(5-6), p. 799-810. 10.2138/am.2007.2281

Ketcham, R.A., Donelick, R.A., and Carlson, W.D., 1999, Variability of apatite fission-track annealing kinetics: III. Extrapolation to geological time scales: American Mineralogist, v. 84(9), p. 1235-1255. 10.2138/am-1999-0903

Khain, V.E., 1994, Geology of Northern Eurasia (Ex-USSR). Second Part: Phanerozoic fold belts and young platforms: Berlin, Gebrüder Borntraeger, 404p.

Less, G., Özcan, E., and Okay, A.I., 2011, Stratigraphy and larger foraminifera of the Middle Eocene to Lower Oligocene shallow-marine units in the northern and eastern parts of the Thrace Basin, NW Turkey: Turkish Journal of Earth Sciences, v. 20(6), p. 793-845.

Lilov, P., Maliakov, Y., and Balogh, K., 2004, K-Ar dating of metamorphic rocks from Strandja massif, SE Bulgaria: Bulgarian Academy of Sciences, Geochemistry, Mineralogy and Petrology, v. 41, p. 107-120.

Machev, P., Ganev, V., and Klain, L., 2015, New LA-ICP-MS U-Pb zircon dating for Strandja granitoids (SE Bulgaria): Evidence for two-stage late Variscan magmatism in the internal Balkanides: Turkish Journal of Earth Sciences, v. 24(3), p. 230-248. 10.3906/yer-1407-21

Miller, C.F., McDowell, S.M., and Mapes, R.W., 2003, Hot and cold granites? Implications of zircon saturation temperatures and preservation of inheritance: Geology, v. 31(6), p. 529-532. 10.1130/0091-7613(2003)031<0529:HACGIO>2.0. $\mathrm{CO} ; 2$

Munteanu, I., Matenco, L., Dinu, C., and Cloetingh, S., 2011, Kinematics of back-arc inversion of the Western Black Sea Basin: Tectonics, v. 30, p. TC5004. 10.1029/2011TC002865

Nachev, I.K., 1981, On the origin of Flysch in Bulgaria: Review of the Bulgarian Geological Society, v. 42(2), p. 143-152.

Natal'in, B.A., Sunal, G., Gün, E., Wang, B., and Zhiqing, Y., 2016, Precambrian to Early Cretaceous rocks of the Strandja Massif (northwestern Turkey): Evolution of a long lasting magmatic arc: Canadian Journal of Earth Sciences, v. 53(11), p. 1312-1335. 10.1139/cjes-2016-0026

Natal'in, B.A., Sunal, G., Satir, M., and Toraman, E., 2012, Tectonics of the Strandja Massif, NW Turkey: History of a long-lived arc at the northern margin of Palaeo-Tethys: Turkish Journal of Earth Sciences, v. 21(5), p. 755-798.

Nikishin, A.M., Okay, A., Tüysüz, O., Demirer, A., Wannier, M., Amelin, N., and Petrov, E., 2015, The Black Sea Basins structure and history: New model based on new deep penetration regional seismic data. Part 2: Tectonic history and paleogeography: Marine and Petroleum Geology, v. 59, p. 656-670. 10.1016/j.marpetgeo.2014.08.018

Okay, A.I., Altıner, D., and Kiliç, A.M., 2015, Triassic limestone, turbidites and serpentinite - the Cimmeride orogeny in the Central Pontides: Geological Magazine, v. 152, p. 460-479. $10.1017 /$ S0016756814000429
Okay, A.I., Satır, M., Tüysüz, O., Akyüz, S., and Chen, F., 2001, The tectonics of the Strandja Massif: Late-Variscan and midMesozoic deformation and metamorphism in the northern Aegean: International Journal of Earth Sciences, v. 90(2), p. 217-233. 10.1007/s005310000104

Okay, A.I., Şengör, A.C., and Görür, N., 1994, Kinematic history of the opening of the Black Sea and its effect on the surrounding regions: Geology, v. 22(3), p. 267-270. 10.1130/0091-7613(1994)022<0267:KHOTOO > 2.3.CO;2

Okay, A.I., Sunal, G., Sherlock, S., Altıner, D., Tüysüz, O.,

Kylander-Clark, A.R.C., and Aygül, M., 2013, Early Cretaceous sedimentation and orogeny on the southern active margin of Eurasia: Central Pontides, Turkey: Tectonics, v. 32, p. 1247-1271. 10.1002/tect.20077

Okay, A.I., and Tüysüz, O., 1999, Tethyan sutures of the northern Turkey, in Durand, B., Jolivet, L., Horvát, F., and Sérrane, M., eds, The Mediterranean Basins: Tertiary Extension within the Alpine Orogen: London, Geological Society of London Special Publication no. 156, p. 475-515.

Okay, A.I., Zattin, M., and Cavazza, W., 2010, Apatite fissiontrack data for the Miocene Arabia-Eurasia collision:

Geology, v. 38, p. 35-38.

Papanikolaou, D., Barghathi, H., Dabovski, C., Dimitriu, R., ElHawat, A., loane, D., Kranis, H., Obeidi, A., Oaie, C., Seghedi, A., and Zagorchev, I., 2004, TRANSMED Transect VII: East European Craton - Scythian Platform - Dobrogea Balkanides - Rhodope Massif - Hellenides - East Mediterranean - Cyrenaica, in Cavazza, W., Roure, F., Spakman, W., Stampfli, G.M., and Ziegler, P.A., eds., The TRANSMED Atlas: The Mediterranean Region from Crust to Mantle: Heidelberg, Springer-Verlag.

Perinçek, D., 1991, Possible strand of the North Anatolian fault in the Thrace Basin, Turkey - An interpretation: American Association of Petroleum Geologists Bulletin, v. 75, p. 241-257. Ricou, L.E., 1995, The plate tectonic history of the past Tethys Ocean, in Nairn, A.E.M., Ricou, L.E., Vrielynk, B., and Dercourt, J., eds., The Tethys Ocean: New York, Plenum Press.

Şahin, S.Y., Aysal, N., Güngör, Y., Peytcheva, I., and Neubauer, F., 2014, Geochemistry and U-Pb zircon geochronology of metagranites in Istranca (Strandja) Zone, NW Pontides, Turkey: Implications for the geodynamic evolution of Cadomian orogeny: Gondwana Research, v. 26(2), p. 755771. 10.1016/j.gr.2013.07.011

Şengör, A.M.C., 1979, Mid-Mesozoic closure of Permo-Triassic Tethys and its implications: Nature, v. 279, p. 590-593. $10.1038 / 279590 \mathrm{a0}$

Şengör, A.M.C., 1984, The Cimmeride orogenic system and the tectonics of Eurasia: Boulder, CO, Geological Society of America Special Paper 195, 82 p.

Sinclair, H.D., Juranov, S.G., Georgiev, G., Byrne, P., and Mountney, N.P., 1997, The Balkan thrust wedge and foreland basin of eastern Bulgaria: Structural and stratigraphic development, in Robinson, A.G., ed., Regional and petroleum geology of the Black Sea and surrounding region: Tulsa OK, American Association of Petroleum Geologists Memoir: v. 68, p. 91-114.

Siyako, M., and Huvaz, O., 2007, Eocene stratigraphic evolution of the Thrace Basin, Turkey: Sedimentary Geology, v. 198, p. 75-91. 10.1016/j.sedgeo.2006.11.008

Stampfli, G., Borel, G., Cavazza, W., Mosar, J., and Ziegler, P.A., Eds., 2001, The Paleotectonic Atlas of the PeriTethyan 
Domain: CD-ROM: Kathlenburg-Lindau, European Geophysical Society.

Stampfli, G.M., and Borel, G.D., 2002, A plate tectonic model for the Paleozoic and Mesozoic constrained by dynamic plate boundaries and restored synthetic oceanic isochrons: Earth and Planetary Science Letters, v. 196(1), p. 17-33. 10.1016/S0012-821X(01)00588-X

Stampfli, G.M., and Borel, G.D., 2004, The TRANSMED transects in space and time: Constraints on the Paleotectonic evolution of the Mediterranean domain, in Cavazza, W., Roure, F., Spakman, W., Stampfli, G.M., and Ziegler, P., eds., The TRANSMED Atlas: The Mediterranean Region from Crust to Mantle: Berlin, Springer Verlag, p. 53-80.

Stampfli, G.M., and Hochard, C., 2009, Plate tectonics of the Alpine realm: London, Geological Society, London, Special

Publication 327, p. 89-111.

Stampfli, G.M., and Kozur, H., 2006, Europe from the Variscan to the Alpine cycles: Geological Society of London Memoir, v. 32, p. 57-82. 10.1144/GSL.MEM.2006.032.01.04

Stewart, C., Nemčok, M., Vangelov, D., Higgins, E., Welker, C., and Meaux, D., 2011, Structural and depositional evolution of the East Balkan thrust belt, Bulgaria: AAPG Bulletin, v. 95 (4), p. 649-673. 10.1306/08181008061

Stovba, S., Khriachtchevskaia, O., and Popadyuk, I., 2009, Hydrocarbon-bearing areas in the eastern part of the Ukrainian Black Sea: Leading Edge, v. 28(9), p. 1042-1045. 10.1190/1.3236373

Sunal, G., Natal'in, B.A., Satir, M., and Toraman, E., 2006, Paleozoic magmatic events in the Strandja Massif, NW Turkey: Geodinamica Acta, v. 19(5), p. 283-300. 10.3166/ ga.19.283-300

Sunal, G., Satir, M., Natal'in, B.A., Topuz, G., and Vonderschmidt, O., 2011, Metamorphism and diachronous cooling in a contractional orogen: The Strandja Massif, NW Turkey: Geological Magazine, v. 148, p. 580-596. 10.1017/ S0016756810001020

Sunal, G., Satir, M., Natal'in, B.A., and Toraman, E., 2008, Paleotectonic position of the Strandja Massif and surrounding continental blocks based on zircon $\mathrm{Pb}-\mathrm{Pb}$ age studies: International Geology Review, v. 50(6), p. 519-545. 10.2747/ 0020-6814.50.6.519

Tchoumatchenco, P., Nikolov, T., and Sapunov, I., 1989, Outline of the Jurassic and Early Cretaceous tectonic evolution in Bulgaria: CR Bulgarian Academy Sciences, v. 42 , p. $99-102$.

Tchoumatchenco, P., and Tronkov, D., 2010, Lithostratigraphic units of Tethyan Type of East Stara Planina Mts and Strandzha Mt. (Veleka Unit), south-east Bulgaria. Correlation essay: CR Academic Bulg Sciences, v. 63, p. 285-294.

Topuz, G., Göçmengil, G., Rolland, Y., Çelik, Ö.F., Zack, T., and Schmitt, A.K., 2013, Jurassic accretionary complex and ophiolite from northeast Turkey: No evidence for the Cimmerian continental ribbon: Geology, v. 41, p. 255-258. 10.1130/G33577.1

Turgut, S., and Eseller, G., 2000, Sequence stratigraphy, tectonics and depositional history in eastern Thrace Basin, NW Turkey: Marine and Petroleum Geology, v. 17(1), p. 61-100. 10.1016/S0264-8172(99)00015-X

Turgut, S., Türkaslan, M., and Perinçek, D., 1991, Evolution of the Thrace sedimentary basin and its hydrocarbon prospectivity, in Spencer, A.M., Ed., Generation, Accumulation, and Production of Europe's Hydrocarbons: Special Publication of European Association of Petroleum Geoscientists 1, p. 415-437.

Vasilev, E., and Dabovski, C., 2010, Tectonostratigraphy of Strandzha Massif: Correlations across the Türkish-Bulgarian Border: Sofia, BAS Guide Book, p. 1-58.

Von Raumer, J.F., and Stampfli, G.M., 2008, The birth of the Rheic Ocean-Early Palaeozoic subsidence patterns and subsequent tectonic plate scenarios: Tectonophysics, 461(1), p. 9-20. 10.1016/j.tecto.2008.04.012

Yanev, S., GöncüOğlu, M.C., Gedik, I., Lakova, I., Boncheva, I., Sachanski, V., Okuyucu, C., ÖzgüL, N., Timur, E., Maliakov, Y., and Saydam, G., 2006, Stratigraphy, correlations and palaeogeography of Paleozoic terranes of Bulgaria and NW Turkey: A review of recent data, in Robertson, A.H.F., and Mountrakis, D., Eds., Tectonic development of the Eastern Mediterranean Region: London, Geol. Soc. London, Spec. Publ. 260, p. 51-67.

Zagorchev, I., and Budurov, K., 1997, Outline of the Triassic palaeogeography of Bulgaria: Albertiana, 19, p. 12-24.

Zonenshain, L.R., and LePichon, X., 1986, Deep basins of the Black sea and Caspian Sea as remnants of Mesozoic backarc basins: Tectonophysics, v. 123, p. 181-212. 10.1016/ 0040-1951(86)90197-6 